\title{
The Rarely Isolated fungi: Arthrinium sacchari, Beltrania querna, and Papulaspora immersa, Potentials and Expectations
}

\author{
Waill A. Elkhateeb ${ }^{1 *}$, Ghoson M. Daba ${ }^{1}$, Marwa O. Elnahas ${ }^{1}$, Paul W. Thomas ${ }^{2,3}$ \\ ${ }^{1}$ Chemistry of Natural and Microbial Products Department, Pharmaceutical Industries Researches Division, \\ National Research Centre, El Buhouth St., Dokki, 12311, Giza, Egypt. \\ ${ }^{2}$ Mycorrhizal Systems Ltd, Lancashire, PR25 2SD, UK. ${ }^{3}$ University of Stirling, Stirling, FK9 4LA, UK. \\ *Corresponding Author:Waill A. Elkhateeb, Chemistry of Natural and Microbial Products Department, \\ Pharmaceutical Industries Researches Division, National Research Centre, El Buhouth St., Dokki, Giza, \\ Egypt.
}

\begin{abstract}
The present review highlights some bioactive secondary metabolites, produced by three rare fungi (Arthrinium sacchari, Papulaspora immersa and Beltrania querna), two of them areendophytes isolated from Guava (Psidium guajava L.) and wheat (Triticum aestivum L.) plants cultivated in El-Wady El-Assiuty, Assiut, Egypt and the third was isolated from soil from Assiut petroleum farm, Assiut, Egypt, involved in medical, pharmaceutical applications.
\end{abstract}

Keywords: Arthrinium sacchari, Beltrania querna,Papulaspora immersa, rare endophytic fungi, biological activities.

\section{INTRODUCTION}

Fungi are keeping surprising us by their capabilities and existence worldwide. The number of identified and isolated fungal species was estimated to be around 13.2 million species [1]. This number will definitely increase after the improvement of molecular identification and sequencing techniques (though such techniques are not so welcomed by majority of mycologists). Screening for fungal strains in unusual niches and remote locations is the golden way to discover novel and rare species. Moreover, investigating the mycobiota inhabiting the newly reclaimed areas can contribute in understanding the fungal flora existing in these areas [2]. However, fungi are ubiquitous as new species can be isolated even from the most well studied areas [3]. Fungi generally and endophytic ones specifically aremarvellous factories that perform as potent biotechnological tools for production of bioactive natural compounds, which could extend healthy life span of humanity (as done by penicillin from centuries), and could successfully substitute some expensive chemicals in industry, and medicine [4].

Currently, more efforts is being devoted to expolre the bioactive compounds of fungal endophytes. Further studies on the isolation and identification of fungi as well as investigating and prospecting their secondary metabolites for biotechnological uses or biologically important application represent a critical need nowadays [5].

The promising biological activities of rare and novel isolates have been previously reported. a novel endophytic fungus Hypocrea lixii, was isolated from pigeon pea exhibited anticancer activity through producing cajanol which exerted cytotoxicity activity towards human lung carcinoma cells (A549) [6]. Trameteshirsute is another novel endophyte that produces podophyllotoxin and other related aryltetra lignans with potent anticancer activities [7].

In this mini review, the distribution, description and biological activities of three fungal species of interest were reported. These rare species are Arthrinium sacchari (Speg.) M. B. Ellis, Beltrania querna Harkn and Papulaspora immersa Hotson. Aiming to understand the infrequent distribution of such species as well as trying to investigate and evaluate possible biologically active compounds originated from such species is very beautiful. 
The Rarely Isolatedfungi: Arthrinium Sacchari, Beltrania Querna, and Papulaspora Immersa, Potentials and Expectation

\section{ARThriniUm SACCHARI (SPEG.) M.B. Ellis Distribution AND ECOLOGY}

The genus Arthrinium is widespread and it shows ecological diversity. It is a saprobe that commonly isolated as an endophytefrom grasses, roots, stems and leaves of various plants, also it isreported as endophyte in lichens and marine algae $[\mathbf{8 , 9}]$.

Arthrinium sacchari colonies grow well on potato dextrose agar, attaining a diameter of $9 \mathrm{~cm}$ after incubation at $28 \pm 1{ }^{\circ} \mathrm{C}$ for 7 days; limited growth (about $1 \mathrm{~cm}$ ) was observed on glucose-Czapek's agar after 7 days. Colonies are compact or widely diff use, black or dark blackish brown (Figs. 1). Conidiophores are 1-1.5 $\mu \mathrm{m}$ thick and septa are numerous and brown. Conidia are one-celled, smooth, almost round in face view, lenticular, solitary, lateral or terminal, frequently flattened, and with a hyaline rim, which is either brown or dark brown, measuring $6-8 \mu \mathrm{m}$ in face view and 3-4 $\mu \mathrm{m}$ in thickness [10].

Arthrinium sacchari was isolated from the phylloplane of Guava (Psidium guajava L.) cultivated in El-Wady El-Assiuty [10].

\section{Arthrinium Sacchari (SPeg.) Natural Products}

Many Arthrinium species gain a wide popularity due to their ability to produce bioactive compounds with important pharmacological and medicinal applications, while other are known to produce industrially important enzymes $[\mathbf{1 1}, \mathbf{1 2}]$.According to the literature review, several compounds with antitumor activity were isolated from the culture extract of Arthrinium sacchari. [12].

It was reported that Arthrinium sacchari produces three novel diterpenes namely: myrocin D, libertellenone $\mathrm{E}$ and libertellenone $\mathrm{F}$ as well as new decarboxyhydroxycitrinone and isocoumarin were isolated from Arthrinium sacchari. Moreover, the production of cytochalasin E, myrocin A and libertellenone $\mathrm{C}$ were reported [12].Also Arthrinium saccharisecreted some enzymes with important industrial applications such as: exocellulase, endocellulase, beta-glucosidase, and xylanase[13].

\section{ARTHRINIUM SACCHARI Biological AND INDUSTRIAL APPLiCATIONS}

This fungus does have several beneficial uses. Angiogenesis is the process of persistent migration, proliferation and differentiation of the endothelial cells and thus enhancing the formation of new blood vessels.Hence, angiogenesis plays an important role in the growth and the progression of tumor cells [14]. The angiogenesis inhibitor that aims to decrease or stop the tumour's blood supply is considered an effective tool that can help in cancer treatment [15]. The studies reported that Arthrinium sacchari produces some bioactive compounds that were able to inhibit the proliferation of the human umbilical artery endothelial cells (HUAECs) and the human umbilical vein endothelial cells (HUVECs). In that study, MTT assay (3-(4,5-dimethylthiazol-2-yl)-2,5-diphenyltetrazolium bromide) was employed to evaluate the antiangiogenetic ability of the isolated compounds [12]. Interestingly, myrocin A and decarboxyhydroxycitrinone produced by Arthrinium sacchari exhibited antiproliferative activity towards both HUAECs and HUVECs, while the libertellenone C showed mild antiproliferative activity against the two c ell lines. On the other hand, cytochalasin E showed the highest activity against the proliferation of both HUAECs and HUVECs where the $\mathrm{IC}_{50}$ which is the concentrations of the compounds required to inhibit the proliferation of $50 \%$ of the cells were 0.0110 and $0.0114 \mu \mathrm{M}$ towards HUAECs and HUVECs respectively, using Ki8751 as a positive control $[12,16]$.

Moreover, it has been discovering that various enzymes produced by some fungi play a crucial role in the production of bioethanol from non-starch materials such as lignocellulosic components of agricultural residues and various crops. Such fungi can deconstruct the plant walls as they produce effective enzymes for the bioconversion of energy crops[13]. The studies reported that the activities of four enzymes: exocellulase, endocellulase, beta-glucosidase, and xylanase for Arthrinium sacchari, and it was found that it was able to produce these enzymes. The enzyme activities tested on crude fungal extracts (cellfree) collected from fungal cultures on Miscanthus after 8 weeks of incubation were $3.1 \mu \mathrm{M}$ glucose $/ \mathrm{min} . \mathrm{mg} /$ protein for exocellulase, $77 \mu \mathrm{M}$ glucose/min.mg/protein for endocellulase, $470 \mu \mathrm{M}$ pNP /min.mg/protein for beta-glucosidase and finally $1786 \mu \mathrm{M}$ xylose /min.mg/protein for xylanase[13].

Comparing to Trichoderma reesei, which is one of the most widely used industrial bioconversion fungus, it was found that after8 weeks of solid substrate cultures of Arthrinium sacchari on 
The Rarely Isolatedfungi: Arthrinium Sacchari, Beltrania Querna, and Papulaspora Immersa, Potentials and Expectation

Miscanthus, the percent biomassweight reduction of Miscanthuswas about 11.4\%, however Trichoderma reesei showed Miscant hus biomass reduction percentage of 12.6\%[13].

This study indicates the significance of Arthrinium sacchari in the bioconversion of energy crops due to its ability to produce some important enzymes that aid in removing the plant cell wall components. Thus, helping in the reduction of fossil fuel carbon dioxide produced into Earth's atmosphere.
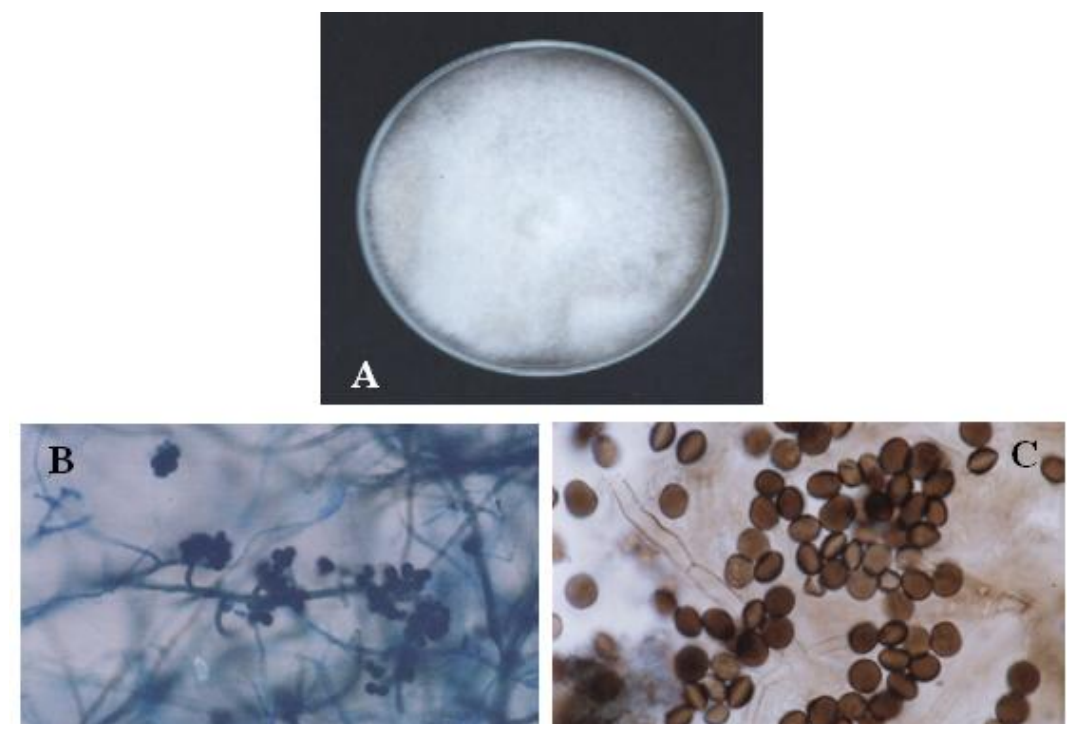

Fig1. Arthrinium sacchari (Speg.)a)Seven-day old colonies on Potato Dextrose Agar, b)A Hyphae, Conidiophores and Conidia (x 400), c) Dark leuticular conidia each with a hyaline rim (x 1000). (Photographs taken by Waill A. Elkhateeb,LocalityAssiut, Egypt).

\section{PAPUlaspora IMMERSA Hotsondistribution AND ECOLOGY}

Colonies reach $6.5 \mathrm{~cm}$ diameter after 7 days of incubation at $28 \pm 1{ }^{\circ} \mathrm{C}$ on PDA and $4 \mathrm{~cm}$ on glucose- Czapek's agar. Papulaspores originate from intercalary cells, are pale brownish yellow, irregular in outline, 88-150 $(-260) \mu \mathrm{m}$ in diameter, often submerged in the agar central cells, and are comparatively large, angular, and darker than the peripheral cells. Reverse brownish yellow (Figs. 2). [10].

Papulaspora immerse was isolated from the phyllosphere of wheat (Triticum aestivum L.) plants cultivated in El-Wady El-Assiuty [10].

\section{Papulaspora Immersa Natural Products}

Tropical endophytes are known to have produced high number of significantly bioactive secondary metabolites [17]. These endophytic fungi showed a greatchemical diversity with respect to their bioactive compounds.Papulaspora immersa is an endophyte in some plant species. This fungus has attracted the attention since it produces some vital bioactive compounds such as antimicrobial agents [18], diketopiperazines [19], taxol [20], amylase and other enzymes [21].

\section{PAPULASPORA IMMERSA BIOLOGICAL ACTIVITIES}

This fungus does have several beneficial uses.Theethyl acetate extract of Papulaspora immersa showed antimicrobial activity against Pseudomonas aeruginosa at MIC of $90 \mu \mathrm{g} / \mathrm{mL}$ using streptomycin sulphate as a positive control, also it showed antimicrobial activity towards Staphylococcus aureus and Kocuria rhizophila at MIC of 240 and 220 respectively using penicillin as a positive control [22].

Moreover, the chloroform extract of Papulaspora immerse allowed the isolation of diketopiperazine compound which is a group of organic compounds that is related to piperazine but contain two amide linkages [23]. Interestingly, these diketopiperazine were found to show antibacterial activity [24] as well as antifungal and antitumor activities [25].

The studies reported that the ethyl acetate extract of Papulaspora immersaexhibited a cytotoxic activity towards several human cell lines including breast tumor cell lines (MDA-MB435),brain tumor 
cell lines (SF295) and colon tumor cell line (HCT-8) where the cell growth inhibition percentages were $95.2 \%, 98.1 \%$ and $100 \%$ respectively [20], employing MTT assay for measuring the cell viability [26].

Additionally, the endophytic fungus $P$. immersawas screened for its ability to producesome enzymes such as amylases, pectinases and cellulases. These enzymes are important for endophytic fungi as they play vital role to assist the fungi colonize in the plant tissue. This experiment was carried out by the plate assay using the starch agar medium, pectin agar medium and carboxy methyl cellulose agar medium to evaluate the production of amylase, pectinase and cellulase respectively. The fungus was allowed to grow in all the inoculated plates and the enzyme activity detection in plate assay was carried out by measuring the clear zone around the growth after applying iodine solution to the plate. Theenzyme index was calculated by dividing the diameter of the formed clear zone including the fungal colony bythe fungal colony diameter [27].The results reported that $P$. immersa from lamina was able to produce the three mentioned enzymes with amalyse enzyme index of 1.19 whereas the pectinase enzyme index was $1.26 \pm 0.02$, and finally cellulase enzyme index was $1.4 \pm 0.01$ [27]

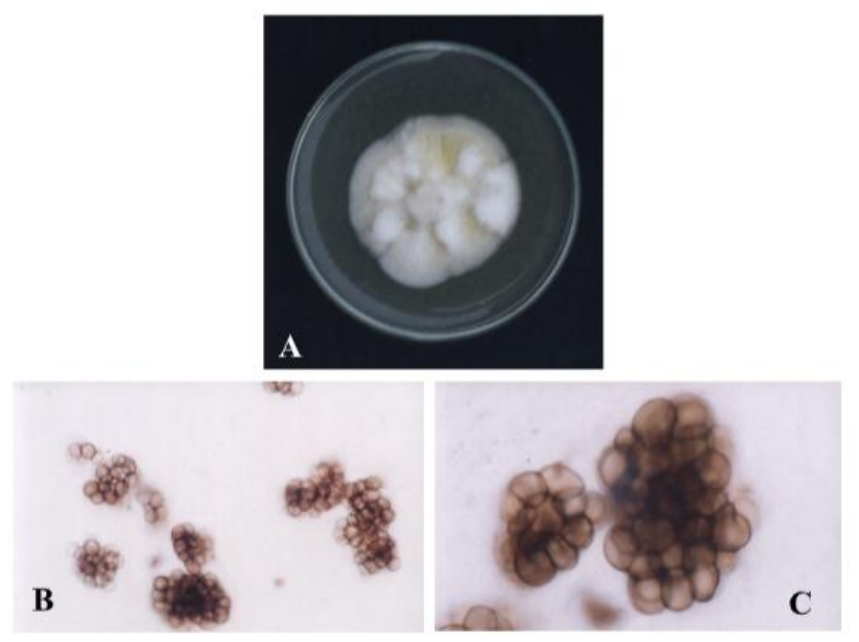

Fig2. Papulaspora immerse hotson: a) Seven-day old colonies on Potato Dextrose Agar,b) Dark irregular papulaspores showing central and peripheral cells. (x 400), c) (x 1000).(Photographs taken by Waill A. Elkhateeb,LocalityAssiut, Egypt).

\section{BELTRANIA QUERNA HARKN DISTRIBUTION AND ECOLOGY}

Beltrania species represent a small proportion of the fungal community.They are a slow growing fungi that is commonly isolated from various oak trees species (Quercus) [28]. The genus Belt rania have unbranched, dark brown pigmented setae and they are characterized by having basal pale yellow-brown conidiophores $(30-150 \times 3.5 \mu \mathrm{m})$ that give rise to conidiogenous cells which proliferate sympodially resulting in separating cellsandconidiawitha lighter pigmented equatorial band and forming asingle apical appendage[29].

Beltrania querna colonies are effuse, brown to black, and attain a diameter of $9 \mathrm{~cm}$ after 7 days of incubation at $28 \pm 1{ }^{\circ} \mathrm{C}$ on potato dextrose agar; stroma usually present setae that are simple, dark, smooth or verrucose, and thickwalled, arising from flat, radially lobed basal cells that are up to 400 $\mu \mathrm{m}$ long (Figs. 3). Conidiophores are straight or flexuous, pale olive to brown, smooth, septate, up to $200 \times 2-7 \mu \mathrm{m}$ conidiogenous cells terminal, polyblastic sympodial, clavate, denticulate, separating cells when present $8-12 \times 4-7 \mu \mathrm{m}$. Conidia are solitary, biconic, appendiculate, the free end usually being spicate, without septa, smooth, and pale olive to dark reddish brown, with a hyaline band. Biconic conidia are mostly asymmetrical, with the proximal end being U-shaped, measuring $15-30 \times$ $7-14 \mu \mathrm{m}$, with a $2-5 \mathrm{~mm}$ appendage [10].

Beltrania querna was isolated from soil collected from Assiut petroleum farm [10].

Although more effort is needed to known more about the bioactive compounds of Beltrania species, it was found that some species showed antimicrobial activities against some infectious strains including Candida albicans and Staphylococcus aureus ATCC25923 with MIC values of 15.6 and $0.98 \mathrm{mg} / \mathrm{ml}$, respectively[30]. 

and Expectation

Moreover, a Beltrania species showed its ability to produce some enzymes with industrial importance. It was reported that the qualitative dot blot method used for qualitative screening of protease showed that Beltrania species secrets protease enzymes and the protease action that appears as colourless spots on the dark blue colored background of the gel was clearly visible [31].

Also, Beltrania species showed its importance for the production of antitumor agents. Two new sesquiterpenes were isolated from the culture broth of Beltrania species [32], and sesquiterpenes are well known to have a potential application as an anticancer agent [33].
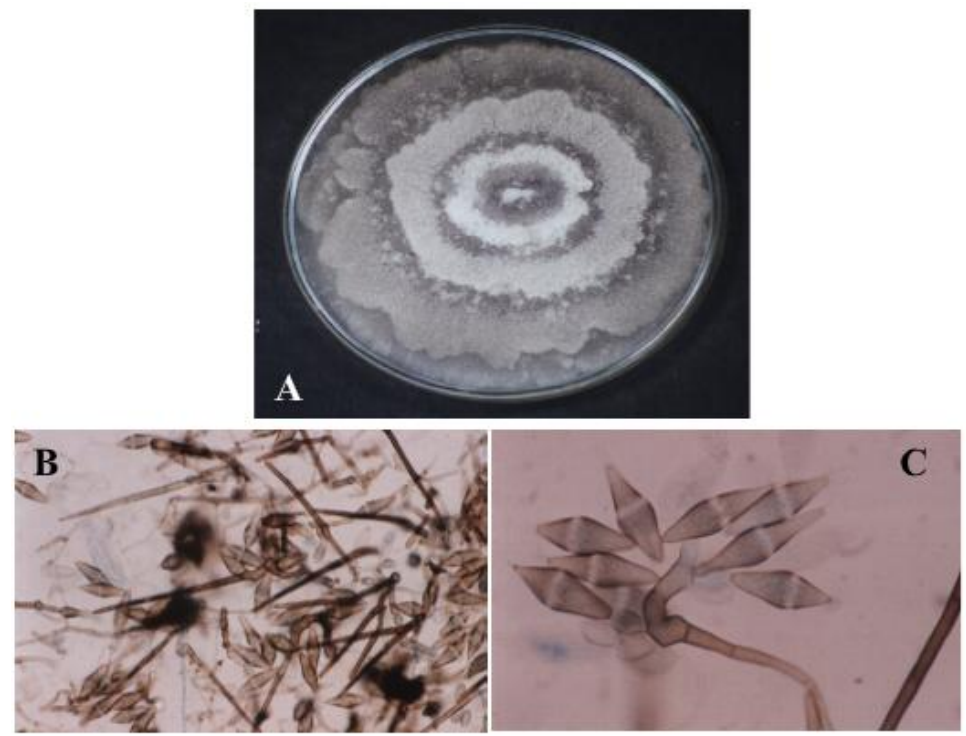

Fig3. Beltrania querna Harkna) fast growing dark colored colony on Potato Dextrose Agar. b) Dark colored conidiophores, setae and conidia $(x 400), c)$ Enlarged part of conidiophore showing the terminal, polybastic sympodial conidiogenous cell, separating cells and the biconic, appendiculate conidia (x 1000).(Photographs taken by Waill A. Elkhateeb,LocalityAssiut, Egypt).

\section{REFERENCES}

[1] Wu B, Hussain M, Zhang W, Stadler M, Liu X, Xiang M. Current insights into fungal species diversity and perspective on naming the environmental DNA sequences of fungi. Mycology, 2019; 10(3), 127-140.

[2] Zohri AN, Elkhateeb WA, Mazen MB, Hashem M, Daba GM. Biologically active fungi recorded for the first time from new reclaimed soil, Egypt. Egyptian Pharmaceutical Journal, 2014; 13(1), 27.

[3] Straatsma G, Ayer F, Egli S. Species richness, abundance, and phenology of fungal fruit bodies over 21 years in a Swiss forest plot. Mycological Research 2001; 105, 515-524.

[4] Daba GM, Elkhateeb WA, Thomas PW. This era of biotechnological tools: an insight into endophytic mycobiota. Egyptian Pharmaceutical Journal, 2018; 17(3), 121.

[5] Elkhateeb WA, Daba GM. Where to Find? A Report for Some Terrestrial Fungal Isolates, and Selected Applications Using Fungal Secondary Metabolites. Biomedical Journal of Scientific \& Technical Research, 2018; 4(3), 4000-4003.

[6] Zhao J, Li C, Wang W, Zhao C, Luo M, Mu F, Fu Y, Zu Y, Yao M. Hypocrea lixii, novel endophytic fungi producing anticancer agent cajanol, isolated from pigeon pea (C ajanus cajan [L.] M illsp.). Journal of applied microbiology, 2013; 115(1), 102-113.

[7] Puri SC, Nazir A, Chawla R, Arora R, Riyaz-ul-Hasan S, Amna T, Ahmed B, Verma V, Singh S, Sagar R, Sharma A. The endophytic fungus Trametes hirsuta as a novel alternative source of podophyllotoxin and related aryl tetralin lignans. Journal of biotechnology, 2006; 122(4), 494-510.

[8] He Y, Zhang Z. Diversity of organism in the Usnea longissima lichen. African Journal of Microbiology Research2012; 6, 4797-4804.

[9] Suryanarayanan T, Raghukumar C. Biology of Marine Fungi. Springer-Verlag Berlin Heidelberg, XVI, $2012 ; 336$

[10] Waill. A. Elkhateeb. Some mycological, phytopathological and physiological studies on mycobiota of selected newly reclaimed soils in Assiut Governorate, Egypt (M. Sc. Thesis, Faculty of Science, Assuit University, Egypt, 2005; p 238.

[11] Crous PW, Groenewald JZ. A phylogenetic re-evaluation of Arthrinium. IMA fungus 2013; 4, 133-154. 
The Rarely Isolatedfungi: Arthrinium Sacchari, Beltrania Querna, and Papulaspora Immersa, Potentials and Expectation

[12] Tsukada M, Fukai M, Miki K, Shiraishi T, Suzuki T, Nishio K, Sugita T, Ishino M, Kinoshita K, Takahashi K. Chemical constituents of a marine fungus, Arthrinium sacchari.Journal of natural products $2011 ; 74,1645-1649$.

[13] Shrestha P, Ibáñez AB, Bauer S, Glassman SI, Szaro TM, Bruns TD, Taylor JW. Fungi isolated from Miscanthus and sugarcane: biomass conversion, fungal enzymes, and hydrolysis of plant cell wall polymers. Biotechnology for biofuels $2015 ; 8,38$.

[14] Kerbel RS. Tumor angiogenesis. New England Journal of Medicine 2008; 358, 2039-2049.

[15] Hayden EC. Cutting off cancer's supply lines. Nature Publishing Group2009.

[16] Udagawa T, Yuan J, Panigrahy D, Chang Y.-H, Shah J, D'Amato RJ. Cytochalasin E, an epoxide containingaspergillus-derived fungal metabolite, inhibits angiogenesis and tumor growth. Journal of Pharmacology and Experimental Therapeutics 2000; 294, 421-427.

[17] An Z. Recent and future discoveries 11 of pharmacologically active metabolites from tropical fungi. Tropical mycology 2002; 2, 165.

[18] Raviraja N, Maria G, Sridhar K. Antimicrobial evaluation of endophytic fungi inhabiting medicinal plants of the Western Ghats of India. Engineering in Life Sciences 2006; 6, 515-520.

[19] Trigos A, Sandoval F. Diketopiperazines from cultures of the fungus Papulaspora immersa. Micol Aplicada Int 2002; 14, 7-9.

[20] Gallo MB, Chagas FO, Almeida MO, Macedo CC, Cavalcanti BC, Barros FW, de Moraes, MO, Costa-Lotufo LV, Pessoa C, Bastos JK. Endophytic fungi found in association with Smallanthus sonchifolius (Asteraceae) as resourceful producers of cytotoxic bioactive natural products. Journal of basic microbiology 2009; 49, 142-151.

[21] Adams P. Mycelial amylase activities of thermophilic species ofRhizomucor, Humicola and Papulaspora. Mycopathologia 1990; 112, 35-37.

[22] Ramos HP, Braun GH, Pupo MT, Said S. Antimicrobial activity from endophytic fungi Arthrinium state of Apiospora montagnei Sacc. and Papulasporaimmersa. Brazilian archives of biology and technology 2010; 53, 629-632.

[23] Dinsmore CJ, Beshore DC. Recent advances in the synthesis of diketopiperazines. Tetrahedron 2002; 58, 3297-3312.

[24] Bycroft BW, Payne DJ. Dictionary of Antibiotics and Related Substances: With CD-ROM, CRC Press 2013.

[25] Mulligan DF, Jones EE, Deacon J. Monitoring and manipulation of populations of Pythium oligandrum, Pythium mycoparasiticum and a Papulaspora species in soil. Soil Biology and Biochemistry 1995; 27, 1333-1343.

[26] Mosmann T. Rapid colorimetric assay for cellular growth and survival: application to proliferation and cytotoxicity assays. Journal of immunological methods 1983; 65, 55-63.

[27] Tuppad DS, Shishupala S. Evaluation of endophytic fungi from Butea monosperma for antimicrobial and enzyme activity. Journal Med Plants Stud 2014; 2, 38-45.

[28] Zucconi L, Pasqualetti M. Microfungal assemblage on Quercus ilex leaf litter in Tuscany, central Italy. Plant Biosystems 2007; 141, 305-313.

[29] Seifert KA, Gams W. The genera of Hyphomycetes-2011 update. Persoonia: Molecular Phylogeny and Evolution of Fungi 2011; 27, 119.

[30] Rukachaisirikul V, Kaewbumrung C, Phongpaichit S, Hajiwangoh Z. Eudesmane sesquiterpenes from the aquatic fungus Beltrania rhombica. Chemical and pharmaceutical bulletin 2005; 53, 238-240.

[31] Thirunavukkarasu N, Suryanarayanan T, Rajamani T, Paranetharan M. A rapid and simple method for screening fungi for extracellular protease. Mycosphere2017; 8, 131-136.

[32] Fraga BM. Natural sesquiterpenoids. Natural product reports 2003; 20, 392-413.

[33] Modzelewska A, Sur S, Kumar SK, Khan SR. Sesquiterpenes: natural products that decrease cancer growth. Current Medicinal Chemistry-Anti-Cancer Agents 2005; 5, 477-499.

Citation: Waill A. Elkhateeb, et.al., (2019). The Rarely Isolated fungi: Arthrinium sacchari, Beltrania querna, and Papulaspora immersa, Potentials and Expectations. ARC Journal of Pharmaceutical Sciences (AJPS), 5(4), pp.10-15. DOI: http://dx.doi.org/10.20431/2455-1538.0504002

Copyright: (C) 2019 Authors. This is an open-access article distributed under the terms of the Creative Commons Attribution License, which permits unrestricted use, distribution, and reproduction in any medium, provided the original author and source are credited. 